\title{
The Emerging Effect of Outside Directors on the Financial Performance of Italian University Spin-Offs ${ }^{1}$
}

\author{
Manuel De Nicola \\ Christian Corsi \\ Antonio Prencipe \\ University of Teramo \\ Via R. Balzarini 1, 64100 Teramo \\ Italy
}

\begin{abstract}
The study of corporate governance is fundamental in university spin-offs (USOs) because their activities are characterized by fast growthbut, jointly, a great risk of market failure cause their knowledge and technology-driven nature, which rise high information asymmetry between management and owners. Furthermore, it is noteworthy that corporate governance affects the performance of the firm.In this view, the paper investigates the effect of outside directorson the financial performance of USOs. Based on a sample of 418 Italian USOs over the period 2010-2014, the results show thatoutside directors arenegatively associated with the financial performance of USOs. The evidence seems to reject the hypothesis that outside directors have a key and superior monitoring and advising role compared to internal directors.
\end{abstract}

Keywords: university spin-offs; USOs; corporate governance; outside directors; firm financial performance.

\section{Introduction}

The last decade show a growing attention of the literature to the growth dynamics of academic entrepreneurship, i.e. university spin-offs (USOs), that are new technology-based firms (NTBFs) usuallywith a small size and established with the support of the university institution and its members, basically professors, researchers, $\mathrm{PhD}$ students, as well as undergraduate and graduate students (Miranda et al., 2018; Hunady et al., 2019; Marzocchi et al., 2019). This form of university venture represents a prospective effective tool in encouraging the generation of socio-economic value, innovation and the expansion of knowledge-based economies (Maier and Birca, 2015). Consequently, the factors linked to their creation, performance and growth have become strategic topics in the policy agenda about the exploitation and the governance of innovation and economic development in definite institutional settings.

The literature attention is chiefly related to the macro, meso and micro determining elements of business performance and growth of university start-ups (Djokovic and Souitaris, 2008) but not among those have been totally explored the aspects linked to their corporate governance. Nevertheless, the importance of corporate governance in USOs is well recognized by the literature (Scagnelli et al., 2019), as well as in firms sharing similar features, such as NTBFs and SMEs operating in the high-tech sector (Colombo et al., 2014). The analysis of the corporate governance assumes a critical importance in USOs because their activities are frequently typifiedby fast growth and high prospects investment opportunities, but jointly with a great risk of market failure in view of their knowledge and technology-driven nature. These features may cause the rise of possibly high information asymmetry between management and owners (Cai et al., 2015). Concurrently, they may cause agency problems, since the purposes and approaches to risk valuation of the principal does not constantly match with those of the agent, particularly in technology and knowledge-based businesses (Hayton, 2005). Furthermore, there are significant evidence that corporate governance affects performance results of the firm (Bhagat and Bolton, 2019). In this emerging setting, internal governance mechanisms, such as those related to the dynamics and composition of the board of directors of the USOs were studied as latent advocates and in the formation and rise of firm economic e non-economic value (Bjørnåli and Gulbrandsen, 2010). On the base of these arguments, this study aims to explore the role played by the board of directors, with specific regard to outside directors, on financial performance of USOs by examining a sample of 418 Italian USOs collected from Netval and Aida databases. Indeed, Italy is one of the main European countries showing a quick increase of the USOs phenomenon (Muscio et al., 2016).

\footnotetext{
${ }^{1}$ Although the research has been carried out jointly, paragraphs 2,3 and 5 have been prepared by Manuel De Nicola, paragraph 1 by Christian Corsi; paragraph 4by Antonio Prencipe.
} 
The study adds, although only partially, new insights to the literature related to the entrepreneurial university, both from a theoretical and empirical perspective. First, the study contributes to the rising body of research on growth and firm performance of USOs by underlining the role of outside directors as a central determinant of firm outcomes. Second, the findings emerging from this study could be generalized beyond the Italian setting, as the European USOs share similar and comparable features (VisintinandPittino, 2014).

\section{Theoretical framework and hypotheses development}

The management and innovation literature show in the last decade a significantly increasing focus on the corporate governance aspects (Belloc et al., 2016; Hussinger et al., 2018) This is especially relevant with regard to the board composition, dynamics and characteristics of its directors. However, the majority of previous studies on corporate governance has been extensively investigated large firms with less evidence for private small and medium sized firms (SMEs) as well as technology- and knowledge-based firms. Consequently, the emerging evidences about USOs are actually limited.

Though, it is to note that in the corporate governance dynamics outside directors has critical role, especially with regard to USOs, influencing the firm evolution and its performance. In detail, taking into account the agency theoretical arguments, superior monitoring mechanisms are needed to protect shareholders from management's self-interests and outside directors are prospective defenders of the shareholders' interests thanks to their monitoring activity. Henceforth, a great part of outside directors on the board might cause a positive outcome on firm performance by means of monitoring facilities (Fama and Jensen, 1983). In accordance with the agency theory, some scholars suggest alternative theoretical explanations with regard to the role of outside directors (Linck et al., 2008). Usually, different typology of independent directors, such as banks, venture capitalists and private equity may bring different assets to the company or serve as strategic stakeholders (Adams et al., 2010). A developing body of research recommends that a strong and aware board of directors may generate positive effects on the value creation in small firms and newfirm's technology and knowledge based, such as university spin-offs, enabling strategic change and firm performance (Gabrielsson, 2007).

Considering the resource-based view theory, small firms such as USOs are usually characterized by limited resources in-house. In this emerging setting, it is fundamental the counselling role of the board (Liu et al., 2015; Johl et al., 2015), as they can keep additional information that can be used by the management in improve their growth strategies (Arosa et al., 2010). In this regard, the existence of outside directors on the board of USOs will reflect the missing resources required for the firm, supporting the enhancement of its outcomes and improving its performance.

Additionally and in line with the resource dependence theory, outside directors are expected to serve as a link mechanism among the firm and its external environment, which might help managers in the execution of the organizational strategic actions (Haynes and Hillman, 2010; Boivie et al., 2016). This is crucial for small technology and knowledge-based firms such as USOs, which need external access to financial and human resources (Daily and Dalton, 1993).

Following the corporate governance literature about the resource dependence theory, scholars remarks that boards of small and new firms, such as USOs, act as annexes to the top management rather than supervising the company (Zahra and Filatotchev, 2004; Zahra et al., 2007). One way for small and new firms unable to hire full-time specialized executives is to appoint part time non-executive directors to the board who might hold superior capability and specific familiarity than the founders of the firm (Zhang, 2011). Hiring well-educated and skilled directors with broad corporate networks is one policy of small and new firms to collect human and social resources to complement the founders' and workforces' know-how, supporting the reach of the company' goals and, consequently, improving the performance of the firm.Henceforth, in view of the above arguments, the following hypothesis has been defined:

H1: The proportion of outside directors of USOs is positively associated with the financial performance of the firm.

However, a negative effect of outside directors is still plausible. Specifically, the financial economics literature offers evidence advocating that outside board members could be more worried about their personal advantages than about the performance of the companies they are believed to monitor and guide (Fahlenbrach et al., 2010, Dou et al., 2015). Additionally, the concepts related to the friendly executive engagements, career interests of board members and time limitations due to additional concurrent board mandates point towards limited monitoring and counselling abilities and, therefore, versus a positive influence of outside directors on performance of the firm.Literature suggest that great institutional owners, such as venture capital that are one of the main investors of USOs (Bock et al., 2018), decrease career concerns of executives by defending them against dismissals subsequently to low firm performance in the shortterm (Aghion et al., 2013). 
Additionally, since USOs are focused in commercialize the innovation generated in the university (Soetanto and Jack, 2016), it is to note that innovation is an expensive and extremely uncertain investment, and executives might be dismissed for not successful innovations for reasons associated to the executive's capability if investors are not able to discriminate among luck and the excellence of executive.

Institutional investors might denote a superior aptitude and better motivations to expose the actual capability of executives than other investors, thus incentivizing executives to promote innovative active and, as a consequence, improve the financial performance of USOs. Scholars claim that the means through which institutional investors influence innovative and financial performance may also concern the board of directors, such that outside directors might have a lesser capacity to expose the role of management quality for innovation and financial performance and development of the firm (Hirsh Leifer et al., 2012; Galasso \& Simcoe, 2011; Schrandt and Zechman, 2012). If this is the circumstance, a greater number of outside directors - conditional on the total size of the board - should have a negative effect on performance of USOs. This means acquire particular relevance if outside directors have no familiarity in managing knowledge and technology-based firms such as USOs. Thus, in view of the above arguments, the following hypothesis has been defined:H2: The proportion of outside directors of USOs is negatively associated with the financial performance of the firm.

\section{Method}

\subsection{Sample}

In order empirical validate the research hypothesis outlined, data about USOs were collected from Netval database, for which information about the whole population of research-based spin-off in Italy are provided. In detail, from the full dataset of the Netval database it was collected only data about USOs, i.e. 1,275 firms. Since Netval database does not provide financial data of the firms, this information has been collected by Aida BdV database. From the 1,275 USOs has been eliminated those firm's data are not available in the Aida BdV database. Consequently, the final panel sample comprises of 418 Italian USOs for the period 2010-2014 with a total of 2,090 firm-year observations.

\subsection{Variables definitions}

\subsubsection{Dependent variable}

The performance measurement of USOs has a significant role in the literature on spin-out processes from academia, as they are the basic drivers measuring effectiveness and efficiency of outcome related to the university entrepreneurship (Siegel et al., 2007; Colombo et al., 2010; Bigliardi et al., 2013; Huynh and Patton, 2014). For this study, the return on equity index (ROE) is the dependent variable has been used as financial performance index, calculated as net income divided by equity.

\subsubsection{Independent variables}

In order to examine the predicted effects of outside directors on the financial performance of USOs, the number of external directors of the board has been used. The aim is to measure the board's monitoring aptitude (OUTSIDE DIRECTORS).

\subsubsection{Control variables}

A set of control variables has been used that may generate a possible effect on the financial performance of the USOs. First, the firm size (SIZE) has been used measured in term of number of firm's employees. Second, the age of the USOs has been used as a measure of the number years from the date they were founded (AGE). Third, an index of company's financial leverage has been used in term of Debt-equity ratio (LEVERAGE). Furthermore, year dummies have been included with the purpose to control for time effects.

\subsection{Analytical approach}

The study of the effects about one of the keys determinants of the corporate governance, i.e. outside directors, on the financial performance re of USOs has been achieved according with a two-steps empirical approach. In the first step, descriptive statistics and Pearson bivariate correlation have been calculated for the full sample analyzed; while, in the second step, an equation has been defined and estimated with linear regression (OLS) to test the research hypothesis. In detail, the defined equation takes the following form:

ROE $_{i t}=f\left(\beta_{0}+\beta_{1}\left(\right.\right.$ OUTSIDE DIRECTORS $_{i t}+\beta_{2}$ FIRM SIZE $_{i t}+\beta_{3}$ FIRM AGE $_{i t}+\beta_{3}$ LEVERAGE $\left._{i t}+\varepsilon_{i t}\right)$

\section{where $i$ indexes USO, $t$ is the time effect and $\varepsilon$ is the error term.}

\section{Results}

\subsection{Descriptive statistics}


Table 1 shows the descriptive statistics of variables used in the study. The results point out that the USOs sampled show an average of the ROE index of 1.50, with a high dispersion in the sample (S.D. $=140.051$ ), highlighting that in the USOs investigated, generally, the financial performance are generally positive but, at the same time, this evidence is unequal within the sample, remarking an high heterogeneity in the performance dynamics of the USOs sampled.

Concerning the dynamics related to the corporate governance of USOs, the results show a medium-low involvement of directors with a sample-wide mean of 1.016, but with a quite low dispersion in the sample (S. D. $=1.26)$. With regard to the features of the USOs, the number of employees reports a sample-wide mean of 2.13 and a moderate dispersion in the sample (S.D. $=6.69$ ). This result points out the overall small size of the USOs investigated. About the age of the USOs, the results report a sample-wide mean of 7.94, remarking that the spin-out process from university is a very recent phenomenon in Italy. Nevertheless, the sample analyzed reports a medium heterogeneity in the age structure of USOs (S.D. =4.01). Finally, the results report that the USOs sampled show an average of leverage index of 4.63, with a high dispersion in the sample (S.D. = 9.05), highlighting that in the USOs explored, usually, the capital structure is quite imbalanced.

Table 1 Descriptive statistics

\begin{tabular}{llllll}
\hline Variable & Obs & Mean & S. D. & Min & Max \\
\hline ROE & 1,804 & 1.5005 & 140.0510 & -1872.9710 & 3426.7260 \\
OUTSIDE & 2,085 & 1.01679 & 1.2592 & 0 & 6 \\
DIRECTORS & 2,090 & 7.9402 & 4.0098 & 1 & 29 \\
AGE & 2,090 & 4.6286 & 6.6887 & 0 & 101 \\
SIZE & 1,811 & 9.0559 & 0.2500 & 195.4000 \\
LEVERAGE & & & & &
\end{tabular}

Table 2 shows the correlation matrix of the variables used for the empirical analysis. The absence of a sufficiently high and significant correlation between the independent variables and control variables used in the defined equation model permits to reject problems related with the potential nonsense correlation (Aldrich, 1995; Cohen et al., 2013). Therefore, multicollinearity was not a serious issue in the empirical analysis.

Table 2 Correlations

\begin{tabular}{|c|c|c|c|c|c|}
\hline & 1 & 2 & 3 & 4 & 5 \\
\hline $1 \mathrm{ROE}$ & 1.0000 & & & & \\
\hline 2 OUTSIDE DIRECTORS & $-0.0489 *$ & 1.0000 & & & \\
\hline 3 AGE & -0.0275 & 0.0206 & 1.0000 & & \\
\hline 4 SIZE & -0.0243 & $0.1109 *$ & $0.3533 *$ & 1.0000 & \\
\hline 5 LEVERAGE & $0.1718^{*}$ & -0.0221 & 0.0001 & $0.0462 *$ & 1.0000 \\
\hline
\end{tabular}

Notes: *Significant at 5\%. 


\subsection{Model estimation}

Table 3 Estimates of the defined OLS models

\begin{tabular}{lll}
\hline & Model & Model \\
\hline Main effects & $(1)$ & $(2)$ \\
OUTSIDE DIRECTORS & & $-4.6805^{* *}$ \\
Control variables & - & $(2.1655)$ \\
AGE & -0.7649 & -0.8136 \\
& $(0.7395)$ & $(0.7340)$ \\
SIZE & -0.4491 & -0.3414 \\
& $(0.4117)$ & $(0.4064)$ \\
LEVERAGE & 2.6563 & 2.6371 \\
& $(3.9218)$ & $(3.9264)$ \\
2011 & -1.0312 & -1.2819 \\
2012 & $(7.6141)$ & $(7.6149)$ \\
2013 & -3.1563 & -3.4360 \\
& $(12.1684)$ & $(12.1892)$ \\
2014 & 7.2961 & 7.0295 \\
& $(11.8097)$ & $(11.9086)$ \\
Number of obs & $-18.1227^{*}$ & $-18.6884^{*}$ \\
R-squared & $(9.4595)$ & $(9.4650)$ \\
Root MSE & & \\
DF & 1,804 & 1,801 \\
& 0.0345 & 0.0364 \\
\hline
\end{tabular}

Table 3 shows the results of the OLS regressions for the defined equation estimating the impact of the outside directors on the financial performance of USOs measured in term of ROE index. The regression analyses are performed in a stepwise manner. Model (1) includes all the control variables; while model(2)refers to the full model. From the model (2), the coefficient on outside directors is negative and statistically significant (coeff. $=-4.6805, \mathrm{p}<0.05$ ), thus providing support to Hypothesis 2 but rejecting the Hypothesis 1. Therefore, the empirical results of the estimated model suggest that outside directors have a negative role for USOs, decreasing their financial performance.

Notes: Robust standard errors in parenthesis.

$* \mathrm{p}<0.01$.

$* * \mathrm{p}<0.05$.

$* * * \mathrm{p}<0.001$.

\section{Result discussion and conclusion}

The paper aimed to investigate the effect of mechanisms related to the corporate governance on financial performance of USOs. Following the existing literature, it was advanced that outside director might have a positive but also a negative effect on the financial performance of USOs, depending on their emerging role from different theoretical perspectives. With the aim to empirical examine the defined hypotheses, a sample of 418 Italian USOs has been explored during the period 2010-2014. The results show that outside directors are negatively associated with the financial performance of USOs. The evidence seems to reject the hypothesis that outside directors have a key and superior monitoring and advising role compared to internal directors. Instead, the emerging findings suggests that outside directors might have an inferior ability to reveal the role of management quality for financial performance, with an effective reduction of their monitoring role, cause to the latent effect of institutional investors - such venture capital - that are typical of technology and knowledge based firms such as USOs.

The study has some interesting practical and policy implications. The emerging results of the study may constitute potential guides for the structure of the board of directors in USOs with the aim to increase their financial performance. In detail, since outside directors seem to no endorse financial performance. In this case, USOs should select and attract outside directors that will be more suitable for the firm. 
Outsider selection is central because should provide professionalism to the board. Indeed, outside directors are valuable to the USOs if they add additional and complementary expertise, in accordance with the institutional investor's expectations and goals. Nevertheless, the study is not free of limitations., which provide new avenues for the future research in the topic. First, although the paper use panel data, the short period of analysis might limit the robustness of the causal associations among the variables explored. Consequently, future studies may will be advantage from collect additional time's series data in a medium-long period, with the purpose to increase the effectiveness of the assumptions related with the causality of the relations taken into account. Second, although there is a good comparability of Italian USOs data with those of the others European countries in view of the similar institutional and entrepreneurial settings, additional data on European USOs as well cross-country analysis are required to increase the generalization the emerging findings and build a more efficient and solid theoretical framework in the topic.

\section{References}

Aghion, P., Van Reenen, J., \& Zingales, L. (2013). Innovation and institutional ownership. American economic review, 103(1), 277-304.

Aldrich, J. (1995). Correlations genuine and spurious in Pearson and Yule. Statistical science, 10(4), 364-376.

Arosa, B., Iturralde, T., \&Maseda, A. (2010). Outsiders on the board of directors and firm performance: Evidence from Spanish non-listed family firms. Journal of Family Business Strategy, 1(4), 236-245.

Belloc, F., Laurenza, E., \& Alessandra Rossi, M. (2016). Corporate governance effects on innovationwhenboth agency costs and assetspecificitymatter. Industrial and Corporate Change.

Bhagat, S., \& Bolton, B. (2019). Corporate governance and firm performance: The sequel. Journal of Corporate Finance, 58, 142-168.

Bigliardi, B., Galati, F., \& Verbano, C. (2013). Evaluating performance of university spin-off companies: Lessons from Italy. Journal of technology management \&innovation, 8(2), 178-188.

Bjørnåli, E. S., \&Gulbrandsen, M. (2010). Exploringboardformation and evolution of board composition in academicspin-offs. The Journal of Technology Transfer, 35(1), 92-112.

Bock, C., Huber, A., \&Jarchow, S. (2018). Growth factors of research-based spin-offs and the role of venture capital investing. The Journal of Technology Transfer, 43(5), 1375-1409.

Boivie, S., Bednar, M. K., Aguilera, R. V., \&Andrus, J. L. (2016). Are boards designed to fail? The implausibility of effectiveboardmonitoring. Academy of Management Annals, 10(1), 319-407.

Cai, J., Liu, Y., Qian, Y., \&Yu, M. (2015). Information asymmetry and corporate governance. Quarterly Journal of Finance, 5(03), 1550014.

Cohen, P., West, S. G., \& Aiken, L. S. (2014). Applied multiple regression/correlation analysis for the behavioral sciences. Psychology Press.

Colombo, M. G., Croce, A., \&Murtinu, S. (2014). Ownership structure, horizontal agency costs and the performance of high-tech entrepreneurial firms. Small Business Economics, 42(2), 265-282.

Colombo, M. G., D’Adda, D., \& Piva, E. (2010). The contribution of university research to the growth of academic start-ups: an empirical analysis. The Journal of Technology Transfer, 35(1), 113-140.

Daily, C. M., \& Dalton, D. R. (1993). Board of directors leadership and structure: Control and performance implications. Entrepreneurship theory and practice, 17(3), 65-81.

Djokovic, D., \&Souitaris, V. (2008). Spinouts from academic institutions: a literature review with suggestions for further research. The Journal of Technology Transfer, 33(3), 225-247.

Dou, Y., Sahgal, S., \& Zhang, E. J. (2015). Shouldindependentdirectorshavetermlimits? The role of experience in corporate governance. Financial Management, 44(3), 583-621.

Fahlenbrach, R., Low, A., \&Stulz, R. M. (2010). The dark side of outside directors: Do theyquitwhenthey are most needed? (No. w15917). National Bureau of Economic Research.

Fama, E. F., \& Jensen, M. C. (1983). Separation of ownership and control. The journal of law and Economics, 26(2), 301-325.

Gabrielsson, J. (2007). Correlates of board empowerment in small companies. Entrepreneurship Theory and Practice, 31(5), 687-711.

Galasso, A., \&Simcoe, T. S. (2011). CEO overconfidence and innovation. Management Science, 57(8), 1469-1484.

Haynes, K. T., \&Hillman, A. (2010). The effect of board capital and CEO power on strategic change. Strategic Management Journal, 31(11), 1145-1163.

Hayton, J. C. (2005). Competing in the new economy: the effect of intellectual capital on corporate entrepreneurship in high- technology new ventures. R\&D Management, 35(2), 137-155. 
Hirshleifer, D., Low, A., \&Teoh, S. H. (2012). Are overconfident CEOsbetterinnovators?. The journal of finance, 67(4), 1457-1498.

Hunady, J., Orviska, M., \&Pisar, P. (2019). What matters: The Formation of University Spin-offs in Europe. Business Systems Research Journal, 10(1), 138-152.

Hussinger, K., Dick, J. M., \&Czarnitzki, D. (2018). Ownership concentration and innovativeness of corporate ventures. Research Policy, 47(2), 527-541.

Huynh, T., \& Patton, D. (2014). The Performance of University Spin-Offs: The Impact of Entrepreneurial Capabilities and Social Networks of Founding Teams during Start-Ups.

Johl, S. K., Kaur, S., \& Cooper, B. J. (2015). Board characteristics and firm performance: Evidence from Malaysian public listed firms. Journal of Economics, Business and Management, 3(2), 239-243.

Linck, J. S., Netter, J. M., \& Yang, T. (2008). The determinants of board structure. Journal of financial economics, 87(2), 308-328.

Liu, Y., Miletkov, M. K., Wei, Z., \& Yang, T. (2015). Board independence and firm performance in China. Journal of Corporate Finance, 30, 223-244.

Maier, L., \&Birca, I. (2015). Spin-off companies and their role in knowledge-based economy. Economie si Sociologie: Revista Teoretico-Stiintifica, (3), 112-121.

Marzocchi, C., Kitagawa, F., \&Sánchez-Barrioluengo, M. (2019). Evolving missions and university entrepreneurship: academic spin-offs and graduate start-ups in the entrepreneurial society. The Journal of Technology Transfer, 44(1), 167-188.

Miranda, F. J., Chamorro, A., \& Rubio, S. (2018). Re-thinking university spin-off: A criticalliteraturereview and a research agenda. The Journal of Technology Transfer, 43(4), 1007-1038.

Muscio, A., Quaglione, D., \&Ramaciotti, L. (2016). The effects of university rules on spinoff creation: The case of academia in Italy. Research Policy, 45(7), 1386-1396.

Scagnelli, S., Vasile, L., \&Apostolov, M. (2019). Survival drivers of post-incubated start-ups: The effect of academic governance. International Journal of Innovation Management, 23(07), 1950062.

Schrand, C. M., \&Zechman, S. L. (2012). Executive overconfidence and the slippery slope to financial misreporting. Journal of Accounting and Economics, 53(1-2), 311-329.

Siegel, D. S., Wright, M., \&Lockett, A. (2007). The rise of entrepreneurialactivityatuniversities: organizational and societal implications. Industrial and Corporate Change, 16(4), 489-504.

Soetanto, D., \& Jack, S. (2016). The impact of university-basedincubationsupport on the innovation strategy of academic spin-offs. Technovation, 50, 25-40.

Visintin, F., \& Pittino, D. (2014). Founding team composition and early performance of university—Based spin-off companies. Technovation, 34(1), 31-43.

Zahra, S. A., \&Filatotchev, I. (2004). Governance of the entrepreneurialthresholdfirm: A knowledge- based perspective. Journal of Management studies, 41(5), 885-897.

Zahra, S. A., Neubaum, D. O., \& Naldi, L. (2007). The effects of ownership and governance on SMEs' internationalknowledge-basedresources. Small Business Economics, 29(3), 309-327.

Zhang, J. (2011). The advantage of experienced start-up founders in venture capital acquisition: evidence from serial entrepreneurs. Small Business Economics, 36(2), 187-208. 